\title{
Somatostatin and somatostatin analogues - are they indicated in the management of acute pancreatitis?
}

\author{
C J McKay, C W Imrie, J N Baxter
}

\begin{abstract}
Somatostatin was first suggested for the treatment of acute pancreatitis more than 15 years ago but despite many studies, its role in the management of this condition remains unclear. The experimental and clinical studies are reviewed and the physiological actions of somatostatin, which may influence the course of acute pancreatitis are examined. It is concluded that although some reports suggest a trend towards improved survival and lessened complication rate with somatostatin treatment, insufficient evidence of benefit exists to support the use of somatostatin or its analogue in the treatment or prophylaxis against acute pancreatitis in routine clinical practice. (Gut 1993; 34: 1622-1626)
\end{abstract}

Somatostatin, a 14 amino acid peptide was discovered more than 20 years ago in the rat hypothalamus. ${ }^{1}$ Since then it has been identified in species from protozoa to humans and in a wide range of mammalian tissues. ${ }^{2}$ As our knowledge of its physiological role expands, so the list of conditions for which it is of potential therapeutic benefit grows longer.

In addition to its use in the management of acromegaly, somatostatin or its analogue, octreotide (SMS 201-995, Sandostatin), has been used in the treatment of acute pancreatitis, pancreatic and enterocutaneous fistulas, ${ }^{34}$ pancreatic pseudocysts, ${ }^{5}$ variceal haemorrhage, ${ }^{6}$ secretory diarrhoeas, ${ }^{7}$ and the short bowel syndrome. ${ }^{8}$ It has also been used successfully in the palliation of some endocrine tumours, most notably carcinoid. ${ }^{9}$

The use of somatostatin in acute pancreatitis was first suggested in $1975^{10} 11$ but despite much experimental and clinical study since that time, its role in the management of this condition remains unclear.

Physiological effects of somatostatin There are four properties of somatostatin in pharmacological doses which may influence the course of acute pancreatitis.

University Department of Surgery, Royal Infirmary, Glasgow C J McKay C W Imrie

J N Baxter

Correspondence to:

$\mathrm{Mr}$ C J McKay, University

Department of Surgery, Royal Department of Surgery, Roy

Accepted for publication 24 March 1993

\section{INHIBITION OF PANCREATIC SECRETION}

It is conventional wisdom that 'to rest the gland' is beneficial in the management of acute pancreatitis. ${ }^{12}$ Although the validity of this assumption has not been established it has led to clinical trials with nasogastric suction, ${ }^{13}{ }^{14}$ cimetidine, ${ }^{15} 16$ and glucagon ${ }^{17}$ in the treatment of acute pancreatitis, none of which has been shown to be effective.

Somatostatin causes a dose dependent reduc- tion in exocrine pancreatic secretion, the effect on enzyme secretion being greater than the effect on secretion of bicarbonate and water. ${ }^{19}$ Similar effects have been shown with the somatostatin analogue, octreotide. ${ }^{2021}$ In health, the doses of somatostatin used in clinical trials would be expected to cause a $70 \%$ reduction in exocrine pancreatic secretion. ${ }^{19}$ This may explain the successful use of somatostatin analogues in the treatment of pancreatic fistulas ${ }^{3}$ and pseudocysts. ${ }^{5}$ The secretory state of the pancreas, however, in acute pancreatitis is unknown, as is the effect of somatostatin on the diseased gland. In experimental models at least, pancreatic secretion seems to remain at basal values ${ }^{22}$ and there is evidence that pancreatic exocrine secretion is impaired in most patients after recovery from necrotising pancreatitis. ${ }^{23}$

\section{HAEMODYNAMIC EFFECTS}

Somatostatin reduces pancreatic blood flow in experimental animals. ${ }^{24}$ The development of pancreatic necrosis has been linked to hypoperfusion of the gland ${ }^{25}$ and vasoconstrictors have been shown to worsen the histological severity of experimental pancreatitis. ${ }^{26}$ Conversely, dopamine, which improves pancreatic blood flow, has been found to improve the outcome from experimental pancreatitis. ${ }^{27}$

Schroder $e$ t al found that, after the induction of pancreatitis, pancreatic blood flow decreased to a greater extent in somatostatin treated piglets than in untreated controls. ${ }^{28}$ This would be expected to be associated with a deleterious effect on outcome although no difference between treated and untreated animals was seen in this study.

\section{CYTOPROTECTION/ORGANOPROTECTION}

Cytoprotective properties have been claimed for somatostatin ${ }^{29} 30$ on the basis of its ability to reduce the effect of various toxins on gastric mucosal cells and hepatocytes. Cytoprotection towards the pancreas, however, has not been proved and experiments have shown that for somatostatin to be effective in this context, pretreatment is necessary. Obviously in acute pancreatitis, where organ damage will have occurred before admission, such pretreatment would not be possible.

\section{STIMULATION OF THE RETICULOENDOTHELIAL} SYSTEM

The fourth way in which somatostatin may influence the course of acute pancreatitis is by its stimulatory effect on the phagocytic cells of the reticuloendothelial system. In experimental 
TABLE I Somatostatin in the treatment of experimental acute pancreatitis

\begin{tabular}{|c|c|c|c|}
\hline Author & Model & $\begin{array}{l}\text { Survival } \\
\text { benefit }\end{array}$ & $\begin{array}{l}\text { Histological } \\
\text { benefit }\end{array}$ \\
\hline Lankisch et $a l^{37}$ & Rat, bile injection & No & No \\
\hline Schwedes et $_{\text {al }}{ }^{38}$ & Dog, bile injection & N/A & Yes \\
\hline Adler et $a l^{+2}$ & Rat, secretagogue & $\mathrm{N} / \mathrm{A}$ & Yes \\
\hline Baxter et $\mathrm{l}^{+3}$ & Rat, duct ligation & Yes & Yes \\
\hline Degertekin et $a l^{\text {to }}$ & Mouse, diet & No & No \\
\hline Schlarman et $^{\text {al }}{ }^{34}$ & Dog, bile injection & N/A & No \\
\hline De Rai $e t a l^{+1}$ & Rat, duodenal loop & No & Yes \\
\hline
\end{tabular}

$\mathrm{N} / \mathrm{A}=$ not assessed; bile injection = retrograde injection of bile or bile salts into the pancreatic duct; secretagogue $=$ intravenous administration of ceruelin; duodenal loop $=$ formation of a closed duodenal loop; diet = administration of a choline deficient, ethionine supplemented diet; duct ligation=ligation of the common bile/pancreatic duct.

acute pancreatitis, survival can be improved by stimulation of the reticuloendothelial system with either zymosan or glucan..$^{31} 32$ Conversely, depression of the reticuloendothelial system results in worsened survival..$^{32}$ There is also some evidence of reticuloendothelial system depression in patients with acute pancreatitis. ${ }^{33}$

Both somatostatin and the longacting somatostatin analogue, octreotide, have been shown to increase the clearance of colloidal carbon..$^{34} 35$ Somatostatin was found to be more effective in this regard than Zymosan. ${ }^{35}$ Somatostatin has also been reported to enhance monocyte phagocytic activity in vitro. ${ }^{36}$ Survival of rats after intraperitoneal injection of endotoxin was also improved with somatostatin treatment, ${ }^{34}$ which may have been a consequence of reticuloendothelial system stimulation.

SOMATOSTATIN IN EXPERIMENTAL PANCREATITIS Somatostatin has been examined in most animal models of acute pancreatitis and has met with varying degrees of success (Table I). In the first study to be reported, ${ }^{37}$ Lankisch et al gave somatostatin at a dose of $100 \mu \mathrm{g} / 100 \mathrm{~g}$ body weight for three hours immediately after inducing pancreatitis in rats by the retrograde injection of sodium taurocholate into the pancreatic duct. Although the serum amylase and lipase were lower in the treatment group, the overall mortality was unchanged. The histological changes in the pancreas were also similar in the two groups. Two years later, Schwedes et al ${ }^{38}$ reported a significant histological benefit with cyclic somatostatin, $62.5 \mu \mathrm{g} / \mathrm{h}$ in a canine model of haemorrhagic pancreatitis. This effect was seen with both somatostatin pretreatment and with somatostatin given two hours after the induction of pancreatitis. The general condition of the animals in the treated group was also noted to be improved.

In addition to the different species used in these experiments, there are differences in experimental design which may help to explain these contradictory results. In inducing acute pancreatitis, Lankisch et al used sodium taurocholate whereas Schwedes et al used the animals own bile. Neither group of workers standardised the injection pressures used, a factor which may influence the severity of pancreatitis produced. There was also a difference in the length of somatostatin treatment between the two studies. Whereas Lankisch et al stopped treatment after three hours, Schwedes et al gave somatostatin by continuous infusion for up to 24 hours. Native somatostatin has a half life in the circulation of only two to three minutes ${ }^{2}$ and it is possible that prolonged treatment in the second study was responsible for the difference in result.

Subsequently, Schlarman et $a l^{39}$ reported no improvement in pancreatic histology after the infusion of native somatostatin $20 \mu \mathrm{g} / \mathrm{kg} / \mathrm{h}$ for five hours immediately after the induction of pancreatitis by retrograde bile injection in dogs, although portal and thoracic duct lymph amylase activities were reduced in the treatment group. Similarly, Degertekin et al,${ }^{40}$ using a diet induced model of acute pancreatitis in mice, failed to show a significant effect on survival or pancreatic histology after the subcutaneous administration of native somatostatin, $30 \mu \mathrm{g}$ every eight hours. In view of the short circulation half life of somatostatin, ${ }^{2}$ however, it is unlikely that such a dose schedule would achieve therapeutic values in plasma. It is therefore difficult to draw firm conclusions from this study.

A beneficial effect of cyclic somatostatin, $5 \mu \mathrm{g} /$ $\mathrm{kg} / \mathrm{h}$, on the histological severity of ceruelin induced pancreatitis was reported by Adler et $a l,{ }^{41}$ treatment being started immediately after the induction of pancreatitis. Similarly, De Rai et $a l^{42}$ showed reduced histological damage with somatostatin given intravenously for nine hours. No information on the timing or dose of treatment was given. Baxter et $a l,{ }^{43}$ in addition to showing a histological benefit with somatostatin treatment, found a dramatic improvement in survival in the treatment group. They continued somatostatin, $4 \mu \mathrm{g} / \mathrm{kg}$ body weight, for up to 24 hours using a duct ligation model in the rat. Similar results were seen even if treatment was started immediately or delayed for 24 hours after duct ligation. These results suggest that differences in duration of treatment, but not in timing of treatment or size of dose, may explain some of the differences in results obtained.

Differences between the experimental models used may also play a part in the contradictory results. In the only study to show a survival difference, Baxter et al induced acute pancreatitis in rats by ligation of the common bile/pancreatic duct. This model is normally associated with pancreatic oedema ${ }^{44}$ although pancreatic necrosis and a high mortality were seen in the control group in this study.

The development of the longacting somatostatin analogue, octreotide, has led to its use in experimental pancreatitis. Its longer half life allows subcutaneous administration avoiding the need for continuous intravenous infusion. The four experimental studies reported to date all show some benefit from octreotide administration (Table II).

In the one study to assess survival, ${ }^{43}$ a dramatic advantage was seen after twice daily subcutaneous octreotide at a dose of $2 \mu \mathrm{g} / \mathrm{kg}$ starting 12 hours after the induction of pancreatitis by pancreatic duct ligation. This survival advantage was similar to that reported by the same authors using native somatostatin. Augelli et $a l^{45}$ were able to show a reduction in histological severity in animals given octreotide, $5 \mu \mathrm{g} / \mathrm{h}$, before the induction of pancreatitis although no effect was seen if treatment was delayed until pancreatitis was established despite continuing treatment for 
TABLE II Octreotide in the treatment of experimental acute pancreatitis

\begin{tabular}{|c|c|c|c|}
\hline Author & Model & $\begin{array}{l}\text { Survival } \\
\text { benefit }\end{array}$ & $\begin{array}{l}\text { Histological } \\
\text { benefit }\end{array}$ \\
\hline $\begin{array}{l}\text { Baxter et al }{ }^{+3} \\
\text { Augelli et al } \\
\text { Davliakos et } a^{+3} \\
\text { Zhu et al }\end{array}$ & $\begin{array}{l}\text { Rat, duct ligation } \\
\text { Dog, bile injection } \\
\text { Dog, ex vivo } \\
\text { Rat, bile injection }\end{array}$ & $\begin{array}{l}\text { Yes } \\
\text { N/A } \\
\text { N/A } \\
\text { N/A }\end{array}$ & $\begin{array}{l}\text { Yes } \\
\text { Yes } \\
\text { Yes } \\
\text { Yes }\end{array}$ \\
\hline
\end{tabular}

Ex vivo $=$ isolated, perfused canine pancreas. Other abbreviations as in Table I.

24 hours. Similarly, Zhu et al ${ }^{46}$ giving octreotide $2 \mu \mathrm{g} / \mathrm{kg} / \mathrm{h}$ showed a reduction in histological severity in a rat bile injection model. Once again, this effect was only seen if treatment was commenced before the induction of pancreatitis.

In the study by Davliakos $e t a l^{47}$ an ex vivo model was used and histological benefit was seen after only one injection of octreotide, even if treatment was delayed until one hour after the induction of pancreatitis. Ex vivo models, however, have been criticised as being unphysio$\operatorname{logical}^{44}$ and their usefulness in evaluating treatment effects remains to be established.

In summary, the evidence from experimental studies is inconclusive although in those studies that continue treatment over a prolonged period there is evidence of some improvement in the treatment group. Differences between studies are not explained by the size of dose or the timing of administration in relation to the induction of pancreatitis. Only one study to date has reported an overall reduction in mortality with somatostatin.

\section{Clinical trials with somatostatin in acute pancreatitis}

The main difficulty in therapeutic trials in acute pancreatitis is that only a very small proportion of those with the disease are likely to benefit significantly from specific treatment and it is therefore necessary to recruit large numbers of patients to be confident of showing a reduction in mortality. As with other proposed treatments in acute pancreatitis, clinical trials with somatostatin have often failed to recruit sufficient patients for meaningful conclusions to be drawn.

After small, uncontrolled reports in the late 1970s suggesting clinical improvement with somatostatin in acute pancreatitis a multicentre study was carried out. ${ }^{48}$ The APTS study (Acute Pancreatitis Treatment with Somatostatin $)^{49}$ was conducted between centres in Germany, Switzerland, and Greece and was intended to include only patients with severe disease. Severe acute pancreatitis was defined as hyperamylasaemia and abdominal pain with three or more of five severity criteria present; shock, ileus, abdominal distension, white cell count greater than 12000 cells/dl, and glucose greater than $150 \mathrm{mg} / \mathrm{dl}$. Somatostatin $250 \mu \mathrm{g} / \mathrm{h}$ or placebo was infused for up to seven days. A total of 77 patients were recruited over a two year period, 36 in the treatment group and 41 in the control group. There were seven deaths in the control group $(17 \%)$ and four in the treatment group (11\%) a difference that fails to reach statistical significance. This led the authors to conclude that somatostatin was of no benefit in acute pancreatitis. It is important to realise, however, that this study has insufficient numbers of patients to exclude a survival advantage as large as $\mathbf{5 0 \%}$. It can be readily calculated from sample size nomograms that more than 200 patients would be required in each group to exclude a type II error where the death in the control group is only $17 \% .{ }^{50}$

The authors found that serum pancreatic enzyme concentrations returned to normal more quickly in the treatment group, but unfortunately no detailed analysis was made of the incidence of complications in the two groups, perhaps reflecting difficulties in collating this information in a multicentre study.

Since 1985 there have been a further three controlled clinical trials reported in English language publications, all of which recruited patients with both mild and severe acute pancreatitis.

Choi et al in Hong Kong ${ }^{51}$ conducted a randomised controlled trial comparing somatostatin with standard treatment in patients with acute pancreatitis. Only 71 patients were recruited of whom 15 had prognostically severe disease based on the presence of three or more positive Glasgow criteria.

Patients were randomised on admission to standard treatment and somatostatin $100 \mu \mathrm{g} / \mathrm{h}$ for two days by continuous intravenous infusion or to standard treatment alone. With such small numbers of patients, it is impossible to assess any effect on mortality alone and indeed there were only three deaths overall, two in the control group and one in the treatment group. There was a statistically significant difference in the complication rate between the two groups, which was mainly accounted for by local complications, in particular 'pancreatic phlegmon', which the authors defined as inflammatory pancreatic swelling seen by computed tomography with associated fluid collection.

A multicentre study was reported by D'Amico et $a l^{52}$ in which a total of 164 patients were recruited over a two year period. Patients with acute pancreatitis of every grade of severity were included resulting in an overall mortality of $5 \cdot 5 \%$. No information was given about the randomisation procedure. Somewhat unusually, patients were divided into those requiring immediate surgery and those needing medical treatment alone based on a clinical and radiological assessment of disease severity. Patients not having immediate surgery were then given either total parenteral nutrition alone or total parenteral nutrition with somatostatin, $250 \mu \mathrm{g} / \mathrm{h}$ for five days. Patients who subsequently worsened and required surgery were excluded from the study. There was a further subdivision of patients into 'haemorrhagic' and 'oedematous' pancreatitis based upon the operative findings and clinical course. Overall, there was a trend towards a reduction in death in the somatostatin treated group, which failed to reach statistical significance ( $2 v 7)$. Again, there were less local complications in the treatment group compared with the control group ( $1 v 5)$ although observer bias cannot be excluded and the numbers are too small to allow meaningful statistical analysis. The hospital stay for the group of patients having surgery was reduced in the somatostatin treat- 
TABLE III Somatostatin and octreotide in the prophylaxis against ERCP induced pancreatitis

\begin{tabular}{|c|c|c|c|}
\hline Author & Patients & Drug & Effect \\
\hline Tulassay et al $l^{* 0}$ & 63 & Octreotide & $\begin{array}{l}\text { Less enzyme rise } \\
\text { less pain }\end{array}$ \\
\hline Cicero et $a l^{\text {ol }}$ & 38 & Somatostatin & $\begin{array}{l}\text { Less enzyme rise } \\
\text { less pain }\end{array}$ \\
\hline Bordas et $a l^{62}$ & 33 & Somatostatin & $\begin{array}{l}\text { Less enzyme rise } \\
\text { less pain }\end{array}$ \\
\hline $\begin{array}{l}\text { Guelrud et } a l^{63} \\
\text { Saari et al }{ }^{04} \\
\text { Borsch et al }{ }^{65} \\
\text { Testoni et } a l^{66} \\
\text { Sternleib et } a l^{67} \\
\text { Binmoeller } \text { et } a l^{68}\end{array}$ & $\begin{array}{r}16 \\
56 \\
20 \\
54 \\
84 \\
245\end{array}$ & $\begin{array}{l}\text { Somatostatin } \\
\text { Somatostatin } \\
\text { Somatostatin } \\
\text { Somatostatin } \\
\text { Octreotide } \\
\text { Octreotide }\end{array}$ & $\begin{array}{l}\text { Less pancreatitis } \\
\text { None } \\
\text { None } \\
\text { None } \\
\text { More pancreatitis } \\
\text { None }\end{array}$ \\
\hline
\end{tabular}

ment group. Overall, however, the complex design of this study makes interpretation of the results difficult.

Recently, Gjorup et $a l^{53}$ have reported a small, randomised controlled trial in which 63 patients with acute pancreatitis received somatostatin 250 $\mu \mathrm{g} / \mathrm{h}$ or placebo for three days. Once again, patients with mild pancreatitis were included and as a result the overall mortality is only $3 \%$. Although no significant differences in mortality or complications were seen between the treatment and placebo groups similar criticisms regarding patient numbers can be applied to this study. It is worth noting, however, that in contrast with the studies by Choi and D'Amico the number of local complications in this study were similar in the two groups.

Several small, controlled studies have been reported in foreign language publications. ${ }^{54-56} \mathrm{In}$ all cases, however, the studies include patients with pancreatitis of every grade of severity and therefore the death rates are low. The complication rates are not reported in sufficient detail to allow any meaningful analysis of clinical outcome.

In summary, no sufficiently large trial has yet been performed for firm conclusions to be drawn on the efficacy of somatostatin in acute pancreatitis. There is, however, some evidence of a trend towards a reduction in death and complication rate with somatostatin. A recent metaanalysis of controlled studies with somatostatin in acute pancreatitis ${ }^{57}$ has claimed to show a survival advantage with treatment but this remains to be confirmed in a large controlled trial.

\section{Somatostatin in prophylaxis against ERCP induced pancreatitis}

Acute pancreatitis is the most common complication after endoscopic retrograde cholangiopancreatography (ERCP) occurring in up to $11 \%$ of cases ${ }^{58}$ although asymptomatic hyperamylasaemia occurs in up to $70 \% .{ }^{59}$ Both somatostatin and octreotide have been evaluated in the prophylaxis against acute pancreatitis after ERCP $^{60-68}$ but the results of controlled clinical trials are conflicting (Table III). The incidence of acute pancreatitis in these studies is low and most studies do not have the statistical power necessary to exclude a therapeutic effect. One exception to this is the study by Guelrud $e t a l^{63}$ who studied a particularly high risk group of patients having pancreatic duct sphincter dilatation and found an overall incidence of acute pancreatitis of $43 \%$. Infusion of somatostatin for 12 hours perioperatively resulted in an incidence of acute pancreatitis of $25 \%$ compared with $75 \%$ in the placebo group. Another study, however, has reported a significant increase in the incidence of acute pancreatitis from $11 \%$ to $34 \%$ after the prophylactic use of octreotide, ${ }^{67}$ suggesting that the use of octreotide may even be harmful.

In conclusion, it is the authors' opinion that the evidence currently available does not support the use of somatostatin or its analogue for the treatment or prophylaxis against acute pancreatitis in routine clinical practice.

1 Krulich L, Dharival APS, McCann SM. Stimulatory and inhibitory effects of purified hypothalamic extracts in growth hormone release from rat pituitary in vitro. Endocrinology 1968; 83: 783-90

2 Reichlin S. Somatostatin. N Engl F Med 1983; 309: 1495-501.

3 Prinz RA, Pickleman J, Hoffman SP. Treatment of pancreatic cutaneous fistulae with a somatostatin analogue. Ann Surg cutaneous fistulae

4 Nubiola P, Badia JM, Martinez-Rodenas F, et al. Treatment of 27 postoperative enterocutaneous fistulae with the long halflife somatostatin analogue SMS 201-995. Ann Surg 1989, 210: $56-8$.

5 Gullo I, Barbara L. Treatment of pancreatic pseudocysts with octreotide. Lancet 1991; 338: 540-1.

6 Jenkins SA, Baxter JN, Corbett W, Devitt P, Ware J, Shields R. A prespective randomised, controlled clinical trial comparing somatostatin and vasopressin for the control of acute variceal haemorrhage. $B M \mathcal{F}$ 1985; 290: 270-8.

7 Gaginella TS, O'Dorisio JE, Fassler JE, Mekhjian HS Treatment of endocrine and non-endocrine secretory diarrheal states with sandostatin. Metabolism 1990; 39: 172-5.

8 Ladefoged K, Christensen KC, Hegnoj JS. Effect of a long acting somatostatin analogue SMS 201-995 on jejunostomy effluents in patients with severe short bowel syndrome. Gut effluents in patient

9 Vinik A, Moattari AR. Use of somatostatin analogue in management of carcinoid syndrome. Dig Dis Sci 1989; 34 (suppl): 14-27S.

10 Boden G, Sivitz MC, Owen OE. Somatostatin suppresses secretin and pancreatic exocrine secretion. Science 1975; 190: 163 .

11 Dollinger HC, Raptis S, Pfeiffer EF. Effects of somatostatin on exocrine and endocrine pancreatic function stimulated by intestinal hormones in man. Horm Metab Res 1976; 8: 74-8.

12 Trapnell $\mathrm{J}$. The natural history and management of acute pancreatitis. Clinics in Gastroenterology 1972; 1: 147-66.

13 Naeije R, Salingret E, Clumeck N, De Troyer A, Devis G. Is nasogastric suction necessary in acute pancreatitis? $B M \mathcal{F}$ 1978;2: $659-60$.

14 Levant JA, Secrist DM, Resin H, Sturdevant RAL, Guth PH. Nasogastric suction in the treatment of alcoholic panNasogastric suction in the treat
creatitis. $\mathcal{F A M A} 1974 ; 229: 51-2$.

15 Hooshang M, Molinari MD, Gardner L, Berk JE, Hoehler FK. Cimetidine in the treatment of acute alcoholic pancreatitis. Gastroenterology 1979; 77: 687-90.

16 Broe PJ, Zinner MJ, Cameron JL. A clinical trial of cimetidine in acute pancreatitis. Surg Gynecol Obstet 1982; 154: 13-6.

17 Death from acute pancreatitis: MRC multicentre trial of glucagon and aprotinin. Lancet 1977; ii: 632-5.

18 Durr HK, Maroske D, Zelder O, Bode J Ch. Glucagon therapy in acute pancreatitis: Report of a double blind trial. Gut 1978; 19: 175-9.

19 Gullo L, Priory P, Scarpignato C, Baldon F, Mattioli G Barbara L. Effect of somatostatin 14 on pure human
pancreatic secretion. Dig Dis Sci 1987; 32: 1065-70.

20 Baxter JN, Ellenbogen S, Roberts N, Mackie CR, Jenkins SA The effects of a somatostatin analogue SMS 201-995 on pancreatic secretion in the pig and man. Surg Res Commun 1988; 4: 215-228.

21 Creutzfeldt W, Lembcke B, Folsch U, Schlesser S, Koop I Effect of somatostatin analogue (SMS 201-995, Sandostatin) on pancreatic secretion in humans. Am $\mathcal{F}$ Med 1987; 82 (suppl 5b): 49-54.

22 Niederau C, Niederau M, Luthen R, Strohmeyer G, Ferrel LD, Grendel JH. Pancreatic exocrine secretion in acute experimental pancreatitis. Gastroenterology 1990; 99: 1120-7.

23 Bozkurt T, Maroske D, Adler G. Exocrine pancreatic function after recovery from necrotising pancreatitis. [Abstract] after recovery from
Digestion $1992 ; 52: 72$

24 Becker RHA, Scholtholt J, Scholens BA. A microsphere study on the effects of somatostatin and secretin on regional blood on the effects of somatostatin and secretin on regional be

25 Popper HL, Necheles H, Russell KC. Transition of pancreatic Popper HL, Necheles H, Russell KC. Transition of pancreatic
oedema into pancreatic necrosis. Surg Gynecol Obstet 1948; 87: 79-82.

26 Klar E, Rattner DW, Compton C, et al. Adverse effects of therapeutic vasoconstrictors in experimental acute pancreatitis. Ann Surg 1991; 214: 168-98. 
27 Donahue PE, Akimoto H, Ferguson JL, Nyhus LM. Vasoactive drugs in acute pancreatitis. Arch Surg 1984; 119: 477-80.

28 Schroder T, Millard RW, Nakajima Y, Gabel M, Joffe SN. Microcirculatory effects of somatostatin on acute pancreatitis. Eur Surg Res 1988; 20: 82-8.

29 Szabo S, Usadel KH. Cytoprotection-organoprotection by somatostatin: gastric and hepatic lesions. Experientia 1982; 38: $254-6$.

30 Usadel KH, Kessler H, Rohr G, Kusterer K, Palitzsch K, Schwedes U. Cytoprotective properties of somatostatins. Schwedes U. Cytoprotective properties
Klin Wochenschr 1986; 64 (suppl 7): 59-63.

31 Browder WI, Sherwood E, Williams D, Jones E, McNamee R, Diluzio N. Protective effect of glucan enhanced macrophage function in experimental pancreatitis. Am F Surg 1987; 153: 25-33.

32 Adham NF, Song MK, Haberfelde GC. Relationship between the functional status of the RES and the outcome of experimentally induced pancreatitis in young mice. Gastroenterology 1983; 84: 461-9.

33 Banks RE, Evans SW, Alexander D, Van Leuvin F, Whicher JT, McMahon MJ. Alpha 2 macroglobulin state in acute pancreatitis. Raised values of alpha 2 macroglobulinprotease complexes in severe and mild attacks. Gut 1991; 32: protease

34 Baxter JN, Jenkins SA, Day DW, Shields R. Effects of a somatostatin analogue on hepatic and splenic reticulo-
endothelial function in the rat. Brf Surg $1985 ; 72: 1005-8$.

35 Szabo S. Somatostatin stimulates clearance and hepatic uptake of colloidal carbon in the rat. Life Sci 1983; 33: 1975.

36 Jenkins SA, Baxter JN. Al-Sumidaie AM, Leinster SJ, Shields R. The effects of somatostatin and SMS 201-995 on experimentally induced pancreatitis in rats and on monocyte activity in patients with cirrhosis and portal hypertension. Klin Wochenschr 1986; 64 (suppl vii): 100-6.

37 Lankisch PG, Koop H, Winckler K, Folsch UR, Creutzfeldt W. Somatostatin therapy of acute experimental pancreatitis. Gut 1977; 18: 713-6.

38 Schwedes U, Althoff PH, Klempa I, Leuschner U, Mothes L Raptis S, et al. Effects of somatostatin on bile induced haptis S, et al. Effects of somatostatin on bile induced 11: 655-61.

39 Schlarman DE, Beinfeld MC, Andrus C, Kaminski DL. Effects of somatostatin on acute canine pancreatitis. Int $\mathcal{F}$ Pancreatol 1987; 2: 247-5

40 Degertekin H, Ertan A, Akdamar K, Yates R, Chen I, Coy H, et al. Effects of somatostatin and a somatostatin agonist on diet induced pancreatitis in the mouse. Peptides 1985; 6: 1345-7.

41 De Rai P, Franciosi C, Contalonieri GM, Andreoni B, Uggeri $F$, Malesci A. Effects of somatostatin in AP induced in rats by injection of taurocholate and trypsin into a temporarily
closed duodenal loop. Int $\mathcal{F}$ Pancreatol 1988; 3: 367-73.

42 Adler G, Koch A, Kern HF. Effect of somatostatin on rat exocrine pancreatic secretory function in normal and exocrine pancreatic secretory function in

43 Baxter JN, Jenkins SA, Cowell DC, Day DW, Roberts NB, Mackie CR, et al. Effects of somatostatin and a long acting somatostatin analogue on the prevention and treatment of experimentally induced pancreatitis in the rat. $\mathrm{Br} \mathcal{F}$ Surg 1985; 72: 382-5.

44 Steer ML in Glazer G, Ranson JHC, eds. Acute pancreatitis, experimental and clinical aspects of diagnosis and management. London: Bailliere Tindall, 1988: 207.

45 Augelli NV, Hussein SM, McKain MM, Fietsam R, Bierema T, Fegley M, et al. Effect of SMS 201-995 (a long acting somatostatin analogue) on bile induced haemorrhagic pancreatitis in the dog. Ann Surg 1989; 55: 389-91.

46 Zhu ZH, Holt S, el-Lbishi MS, Grady T, Taylor TV, Powers RE. A somatostatin analogue is protective against retrograde bile salt-induced pancreatitis in the rat. Pancreas 1991; 6: 609-13.

47 Davliakos GP, Petraiulo WJ, Sell HW, Smith W, Marrangoni AG. Treatment of experimentally induced pancreatitis in exvivo perfused canine pancreas with the somatostatin analogue, octreotide. Curr Surg 1990; 47: 343-5.
48 Usadel KH, Leuschner U, Oberla KK. Treatment of acute pancreatitis with somatostatin: a multi-centre, double-blind trial. N Engl f Med 1980; 303: 999-100

49 Usadel KH, Leuschner U, Oberla KK. Treatment of acute pancreatitis with somatostatin. Results of a multicentre trial (the APTS study). [Abstract]. Dig Dis Sci 1985; 30: 992.

50 Young MJ, Bresnitz EA, Strom BL. Sample size nomograms for interpreting negative clinical studies. Ann Intern Med 1983; 99: 248-51.

51 Choi TK, Mok F, Zhan WH, Fan ST, Lai ECS, Wong J. Somatostatin in the treatment of the acute pancreatitis; a Somatostatin in the treatment of the acute pancreatitis; prospecti.

52 D'Amico D, Favia G, Biasiato R, Casaccia M, Falcone F, Fersini $M$, et al. The use of somatostatin in acute pancreatitis. Results of a multicentre trial. Hepatogastroenterology 1990; 37: 92-8.

53 Gjorup I, Roikjaer O, Andersen B, Burcharth F, Hovendal C Pedersen SA, et al. A double-blinded multicentre trial of somatostatin in the treatment of acute pancreatitis. Surg Gynecol Obstet 1992; 175: 397-400.

54 Bottani G, Lecev M, Rovati L. L'uso della somatostatina nella terapia della pancreatite acuta: studio clinico controllato. Minerva Chir 1985; 40: 1337-40.

55 Russello D, Puleo S, Li Destri G, Scuderi M, Latteri F. Ruolo della somatostatina e della nutrizione parenterale nel drattamento della pancreatite acuta. Minerva Chir 1989; 44: trattam.

56 Cimarelli S, Anglesio V, Giovanelli A, Bavuso D. L'uso della somatostatina nelle pancreatite acuta di origine biliare. Minerva Med 1987; 78: 483-7.

57 Carballo F, Dominguez E, Fernandez-Calvet L, MartinezPancorbo C, Garcia A, De la Morena J. Is somatostatin useful in the treatment of acute pancreatitis? A metaanalysis. Digestion 1991; 49: 12-3.

58 LaFerla G, Gordon S, Archibald M, Murray WR. Hyperamylasaemia and acute pancreatitis following endoscopic retrograde cholangiopancreatography. Pancreas 1986; 1 : retrograde.

59 Skude G, Wehlin L, Marauama T, Ariyama J. Hyperamylasaemia after duodenoscopy and retrograde cholangioamylasaemia after duodenoscopy and retro

60 Tulassay Z, Papp J. The effect of the long acting somatostatin analogue on enzyme changes after endoscopic pancreatography. Gastrointest Endosc 1991; 37: 48-50.

61 Cicero GF, Laugier R, Sahel J, Manganero M, Sarles H. Effects of somatostatin on clinical, biochemical and morphological changes following ERCP. Ital f Gastroenterol 1985; 17: 265-8.

62 Bordas JM, Toledo V, Mondelo F, Rodes J. Prevention of pancreatic reactions by bolus somatostatin injection in patients undergoing endoscopic retrograde cholangio政 Res 1988; 29: 106-8.

63 Guelrud M, Mendoza S, Viera L, Gelrud D. Somatostatin prevents acute pancreatitis after pancreatic duct sphincter prevents acute pancreatitis after pancreatic duct sphincter
hydrostatic dilatation in patients with idiopathic recurrent hydrostatic dilatation in patients with idiopath

64 Saari A, Kivilaakso E, Schroder T. The influence of somatostatin on pancreatic irritation after pancreatography. A experimental and clinical study. Surg Res Comm 1988; 24: 271-8.

65 Borsch G,Bergbauer M, Nebel W, Sabin G. Effect of somatostatin therapy on amylase level and pancreatitis rate following ERCP. Med Welt 1984; 35: 109-12.

66 Testoni P, Masci E, Bagnalo F, Titobello A. Endoscopic papillosphincterotomy: prevention of pancreatic reaction by somatostatin. Ital F Gastroenterol 1988; 20: 70-3.

67 Sternleib J, Aronchick C, Retig J, Dabeyeis M, Saunder F, Goosenberg R, et al. A multicentre, randomised, controlled trial to erg R, et al. A multicentre, randomised, controlled pancreatitis [Abstract]. Am f Gastroenterol 1990; 85: 1260.

68 Binmoeller KF, Harris AG, Dumas R, Grimaldi C, Delmon JP. Does the somatostatin analogue octreotide protect against ERCP induced pancreatitis? Gut 1992; 33 1129-33. 